\title{
Prevalence and workplace correlates of tobacco smoking among male expatriate workers in Riyadh, Saudi Arabia
}

Hyacinth O. Ukuhor ${ }^{1}$ and Alkhamis A. Abdulwahab ${ }^{1}$

${ }^{1}$ Department of Public Health, Saudi Electronic University, Riyadh, Saudi Arabia (Correspondence to: H.O. Ukuhor: hyacoo20oo@yahoo.com).

\begin{abstract}
Background: Immigrant populations in Saudi Arabia face significant health inequalities, including higher smoking prevalence and lower tobacco cessation rate, but little is known about smoking among expatriate workers.

Aims: To identify the prevalence and workplace correlates of current smoking to enable targeted anti-smoking interventions.

Methods: A cross-sectional survey of 4575 male expatriate workers was used to investigate the associations between self-reported tobacco smoking, sociodemographic characteristics, industry and occupation groups, health insurance status and overall health status using logistic regression analyses.

Results: Current smoking prevalence was $22.9 \%$ among male expatriate workers, which was lower than the estimated prevalence in the general population $(25.9 \%$ ). Factors significantly associated with current smoking included being married but not living with family [adjusted odds ratio (AOR) $=1.278$, 95\% confidence interval (CI) 1.048-1.560), health insurance coverage ( $\mathrm{AOR}=1.326,1.124-1.565)$, manual ( $\mathrm{AOR}=1.600,1.234-2.075)$ and unskilled ( $\mathrm{AOR}=1.788,1.341-2.383)$ occupations, monthly income $>2000$ Saudi riyal and duration of stay $\geq 1$ year.

Conclusions: Concerted efforts at the national (health policies)and employers' levels are required to reduce smoking prevalence among male expatriate workers, including provision of comprehensive health insurance with tobacco cessation therapy as benefits, enforcement of workplace smoking ban, anti-tobacco heal th programmes and web/telephone smoking cessation counselling.
\end{abstract}

Keywords: expatriate workers, tobacco smoking, sociodemographics, workplace, tobacco cessation initiatives.

Citation: Ukuhor HO; Abdulwahab AA. Prevalence and workplace correlates of tobacco smoking among male expatriate workers in Riyadh, Saudi Arabia. East Mediterr Health J. 2018;24(12):1155-1164. https://doi.org/10.26719/emhj.18.005

Received: 26/02/17; accepted: 22/08/17

Copyright (C) World Health Organization (WHO) 2018. Some rights reserved. This work is available under the CC BY-NC-SA 3.o IGO license (https:// creativecommons.org/licenses/by-nc-sa/3.o/igo).

\section{Introduction}

Tobacco smoking is one of the leading preventable causes of many adverse health outcomes (1). There are about 1 billion smokers globally and in the middle-age groups, tobacco consumption is the primary risk factor for premature deaths among men. Premature death of smokers dispossesses families of income, increases healthcare costs and slows down economic advancement (2). Therefore, the prevention of smoking is a crucial factor in workplace health promotion. Saudi Arabia is ranked fourth in the world in terms of tobacco sales and importation (3). Every year, $>4700$ individuals die from tobacco-related disease, while $>116000$ children and 2889000 adults continue to use tobacco daily and 159100 individuals currently use smokeless tobacco (4). An overall prevalence of $12.2 \%$ has been reported, with men more likely than women to smoke (21.5\% vs. 1.1\%). Additionally, $23.3 \%$ of the Saudi population, $32.3 \%$ of men and $13.5 \%$ of women, are exposed to secondary smoke for at least 24 hours/week at home, work or school (5). Saudi Arabia has a smokefree workplace policy, but it is not strictly enforced (4), and recently announced VAT on tobacco products that commenced in the second quarter of 2017. However, the World Health Organization (WHO) estimates that if smoking prevention interventions continue at the same pace in Saudi Arabia, 6 268400 individuals, about 24\% of the population, will be tobacco smokers by 2025 (1). Furthermore, WHO member states including Saudi Arabia have agreed a target of $30 \%$ relative reduction in tobacco use worldwide among individuals aged $\geq 15$ years by 2025 with 2010 levels as baseline (6). Yet, a recent study suggested widespread tobacco smoking cessation as the most important way to achieve this goal (7).

Sadly, comprehensive and specific health information for the expatriate population in Saudi Arabia is practically unavailable. Specific health data for expatriate workers, including tobacco consumption, are limited to a small cross-sectional study conducted with 421 expatriate Indian workers living in Jeddah, Saudi Arabia (8). The study found a high prevalence of smoking with most participants citing stress, loneliness, financial responsibilities and lack of socializing as reasons for their smoking habit. Moreover, immigrant populations face significant health inequalities, including higher smoking prevalence and lower tobacco cessation rates $(9,10)$. Nonetheless, targeted workplace interventions are effective in reducing smoking prevalence and exposure to secondary smoke (11). No study to our knowledge has comprehensively investigated the prevalence and workplace correlates of tobacco smoking among male 
expatriate workers. Therefore, this study investigated the prevalence, sociodemographic characteristics, and industrial and occupational groups associated with current smoking in a representative sample of expatriate workers in Saudi Arabia. The overall goal was to enable targeted smoking cessation programmes to be conducted, especially among industrial and occupational groups with a large population of workers that otherwise might be difficult to reach. The rationale was that the workplace disparities in the prevalence and correlates of smoking could be a challenge for the initiatives to prevent smoking among this group.

\section{Methods}

\section{Study design}

This was a cross-sectional survey conducted with 4575 male expatriates in businesses/companies that were identified from the Saudi Ministry of Labour database (sampling frame) and the methods have been reported elsewhere (12).A stratified multistage business/company systematic selection design with an equal chance of each expatriate worker being selected from the target population was used. Participant businesses/companies were stratified based on location, business type, company size and number of employees. The first stage divided the companies/businesses in Riyadh into 10 economic sectors. The second stage sampling divided the companies/businesses depending on the size of their expatriate workforces into 4 categories: < 10, 10-24, 25-49 and $\geq 50$. It was estimated that $70 \%$ of the 3.6 million eligible expatriate workers had access to appropriate medical care as a result of the implementation of the compulso-

\section{Eligible expatriate population}

$$
\text { Sampling sites }
$$

Selected companies

Completed companies

Selected expatriate workers

Completed expatriate workers ry health insurance policy. To estimate the percentage with accuracy to within $2 \%$ and $95 \%$ confidence interval (CI), 2000 employees were required for the survey, but because cluster sampling was used, the 2000 employees were multiplied by the design effect, which was taken to be 2 . Therefore, the sample size needed was 4000 expatriate workers. The calculation was done in Epi-Info 3.5.1. In order to determine how many samples were needed for each economic sector and company size, the sample size (4000) was divided by the total number of companies (102 495) in Riyadh. The fraction was used to multiply the total number of companies in each economic sector, to determine the number of companies to be selected from each economic sector, and rounded each number to the nearest absolute value. Each company was assigned a minimum of 30 samples to be surveyed during the selection process. If the company had $<30$ workers, another randomly selected company with a similar size was studied to reach the 30 workers representing both the sector and company size. However, more companies were added for some sectors to have a minimum of 4 companies covering all 4 different sizes of companies. Based on their size and economics sectors, companies were randomly selected from the database by systematic random sampling. During randomization using SPSS version 22.0, companies' names and any related information were concealed. The means of identification were the companies' code numbers that were known only to the Manager of the Department of Statistics at the Ministry of Labour. In addition, twice the number of companies needed were selected in case some companies did not meet the criteria mentioned. Due to this adjustment, the sample size of participants in the study increased to 4629 (Figure 1).

\begin{tabular}{l} 
Selected companies \\
Completed companies \\
Selected expatriate workers \\
Completed expatriate workers \\
$\qquad \begin{array}{l}\text { 54 refused participation and } \\
\text { did not sign the consent form }\end{array}$ \\
\hline
\end{tabular}




\section{Data collection procedure}

Employees in the selected organizations were approached after obtaining approval from the company owner and/ or general manager. The human resources department of large businesses/companies provided a list of expatriate staff from which participants were randomly selected. Participants were approached for interviews during break/lunch time or at the close of work. The purpose of the study was explained to all participants. Additionally, anonymity and confidentiality were assured and the right to refuse participation without affecting their healthcare and employment was explained. All participants gave signed consent and freely agreed to participate in the study. All participants were asked for permission to publish the study findings. Ethical approval was obtained from the Ethical Review Board at King Abdullah International Medical Research Centre, Riyadh, Saudi Arabia.

This study was part of a major study that investigated expatriates' access and barriers to healthcare (12). To ensure uniform data collection, 10 research assistants who spoke the dominant languages of the expatriate workers were recruited for the survey and trained in interview techniques. A pilot study was conducted with 150 expatriate workers to test the questionnaire and procedures.

\section{Measurement tools}

The main dependent variable of interest was whether or not an individual reported tobacco smoking. The 3 recommended basic questions by WHO that must be included in all surveys that measure tobacco exposure were used to assess participants' exposure to tobacco smoking (13). Participants were asked if they smoked cigarettes, moasel or water pipe according to: current tobacco smoking status, past daily smoking status (for current less than daily smokers), and past smoking status (for current nonsmokers). Those who responded that they had no lifetime history of smoking were categorized as never-smokers and those who indicated they smoked every day were classified as everyday smokers. Participants who reported smoking some days were grouped as occasional smokers and those who indicated a history of smoking but did not currently smoke at all were classified as ex-smokers. In this study, we merged everyday and occasional smokers to produce the category current smokers. Therefore, current smokers referred to participants who smoked at least once in the 30 days before the survey.

The independent variables were (A) sociodemographic characteristics: nationality, native language, age, education, income, marital status, and duration of stay in Saudi Arabia; (B) occupational and industrial groups; and (C) overall health and health insurance status. To assess health status, participants were asked to rate their overall health with 5 response options: excellent, very good, good, fair and poor. The variable used in this analysis had 2 categories after merging very good and good with excellent, and fair with poor (excellent and poor). These variables were assessed using the validated Medical Expenditure Panel Survey questionnaire (14).

\section{Statistical analysis}

The dat a were analysed with SPSS for Windows version 24.o. Data were processed using univariate analysis and logistic regression. Prevalence estimates related to age, self-reported health, marital status, income and nationality were calculated and described among the multiple categories of smoking (never, current and ex-smokers) using $\chi^{2}$ analysis. We then examined bivariable associations between all variables and current smoking using logistic regression. Next, we selected variables that were associated with current smoking at a level of $\mathrm{P} \leq 0.05$ based on the Wald test for multivariable logistic regression analysis to develop the final model. The variables were entered into logistic regression as categorical variables, indicator and first. Statistical significance was based on 2-tailed tests and level of significance was set at 0.05 .

\section{Results}

We identified 4629 eligible participants and 4575 successfully completed the interviews, generating a response rate of $98.83 \%$. Sociodemographic, workplace and tobacco smoking status of expatriate workers is shown in Table 1.The largest groups of expatriate workers were from Bangladesh (25.3\%); spoke Arabic (32.4\%); were aged 30-49 years (69.4\%); were manual workers (45.1\%); had a monthly income of $\leq 2000$ Saudi riyal (67.4\%);were married but with families living outside Saudi Arabia (65.2\%); and had completed elementary or high school (36.1\%). Overall, $22.9 \%$ of the participants reported that they currently smoked, with $4.8 \%$ reporting that they had quit smoking; $33 \%$ of participants lacked health insurance coverage, while $96 \%$ reported their overall health as excellent or very good.

Examining these correlates at the same time modified their associations with current smoking. The bivariable analysis indicated that current smoking was significantly associated with native language, education, and marital status. Participants' level of income, duration of stay in Saudi Arabia $\geq 1$ year, and those with health insurance coverage had greater prevalence of current smoking. Occupation and type of industry were also associated with increased risk of smoking. However, the associations between current smoking and age group, self-reported health status and nationality were not significant $(\mathrm{P}>$ 0.05).

Table 2 shows the multivariable logistic regression for current smoking. Relative to Arabic speakers the odds of smoking were reduced for non-Arabic speakers, except participants who spoke Malayalam were 1.3 times more likely to be current smokers. Participants with diploma/ university education were less likely to be current smokers compared to participants with primary school or less education. Participants with monthly income > 2000 Saudi riyal were 1.3 times more likely to be current smokers relative to expatriates on income $\leq 2000$ Saudi riyal. The odds of smoking were significantly greater for participants with monthly income $>6000$ Saudi riyal. Additionally, the odds of smoking were 1.3 times higher for participants who had resided in Saudi Arabia 


\begin{tabular}{|c|c|c|c|}
\hline Variables & $\begin{array}{c}\text { Categories Total }(n=4575) \\
\text { n (\%) }\end{array}$ & $\begin{array}{l}\text { Current smoking } n(\%) \\
1046(22.9 \%)\end{array}$ & $\mathbf{P}^{*}$ \\
\hline Nationality & & & 0.973 \\
\hline Indian & $1100(24.0 \%)$ & $253(24.2 \%)$ & \\
\hline Bangladeshi & $1159(25.3 \%)$ & $274(26.2 \%)$ & \\
\hline Pakistani & $498(10.9 \%)$ & $112(10.7 \%)$ & \\
\hline Egyptian & $81917.9 \%)$ & $178(17.0 \%)$ & \\
\hline Philippine & $200(4.4 \%)$ & $44(4.2 \%)$ & \\
\hline Yemeni & $234(5.1 \%)$ & $56(5.4 \%)$ & \\
\hline Others & $565(12.3 \%)$ & $129(12.3 \%)$ & \\
\hline Native language & & & $<0.001$ \\
\hline Arabic & $1480(32.4 \%)$ & $295(28.2 \%)$ & \\
\hline Urdu & $949(20.7 \%)$ & $189(18.1 \%)$ & \\
\hline Hindi & $443(9.7 \%)$ & $104(9.9 \%)$ & \\
\hline Malayalam & $171(3.7 \%)$ & $53(5.1 \%)$ & \\
\hline Bengali & $1111(24.3 \%)$ & $318(30.4 \%)$ & \\
\hline Tagalog & $182(4.0 \%)$ & $40(3.8 \%)$ & \\
\hline Others & $239(5.2 \%)$ & $47(4.5 \%)$ & \\
\hline Age category (yr) & & & 0.178 \\
\hline$<30$ & $1014(22.2 \%)$ & $212(20.3 \%)$ & \\
\hline $30-49$ & $3176(69.4 \%)$ & $750(71.7 \%)$ & \\
\hline$\geq 50$ & $385(8.4 \%)$ & $84(8.0 \%)$ & \\
\hline Education & & & $<0.001$ \\
\hline Primary school or lower & $1331(29.1 \%)$ & $387(37.0 \%)$ & \\
\hline Elementary or high school completed & $1654(36.1 \%)$ & $379(36.2 \%)$ & \\
\hline Diploma or university degree & $1590(34.8 \%)$ & $280(26.8 \%)$ & \\
\hline Monthly income (SAR) (monthly) & & & $<0.001$ \\
\hline$\leq 2000$ & $3085(67.4 \%)$ & $752(71.9 \%)$ & \\
\hline $2001-6000$ & $1342(29.3 \%)$ & $254(24.3 \%)$ & \\
\hline$>6000$ & $148(3.2 \%)$ & $40(3.8 \%)$ & \\
\hline Marital status & & & $<0.001$ \\
\hline Single/divorced & $842(18.4 \%)$ & $172(16.4 \%)$ & \\
\hline Married, family in KSA & $750(16.4 \%)$ & $111(10.6 \%)$ & \\
\hline Married, family outside KSA & $2983(65.2 \%)$ & $763(72.9 \%)$ & \\
\hline Duration of stay in KSA (yr) & & & 0.013 \\
\hline$<1$ & $818(17.9 \%)$ & $161(15.4 \%)$ & \\
\hline $1-5$ & $2233(48.8 \%)$ & $548(52.4 \%)$ & \\
\hline$>5$ & $1524(33.3 \%)$ & $337(32.2 \%)$ & \\
\hline Occupational group ${ }^{a}$ & & & $<0.001$ \\
\hline Specialist/professionals & $1189(26.0 \%)$ & $188(18.0 \%)$ & \\
\hline Manual workers & $2064(45.1 \%)$ & $515(49.2 \%)$ & \\
\hline Unskilled workers & $1322(28.9 \%)$ & $343(32.8 \%)$ & \\
\hline Industrial group ${ }^{b}$ & & & 0.008 \\
\hline Agriculture & $115(2.5 \%)$ & $20(1.9 \%)$ & \\
\hline Mining & $78(1.7 \%)$ & $23(2.2 \%)$ & \\
\hline Manufacturing & $644(14.1 \%)$ & $159(15.2 \%)$ & \\
\hline Power, utilities & $100(2.2 \%)$ & $17(1.6 \%)$ & \\
\hline Construction & $905(19.8 \%)$ & $230(22.0 \%)$ & \\
\hline Trade & $1467(32.1 \%)$ & $330(31.5 \%)$ & \\
\hline Transportation & $242(5.3 \%)$ & $64(6.1 \%)$ & \\
\hline Finance & $184(4.0 \%)$ & $38(3.6 \%)$ & \\
\hline Education & $692(15.1 \%)$ & $126(12.0 \%)$ & \\
\hline Others & $148(3.2 \%)$ & $39(3.7 \%)$ & \\
\hline
\end{tabular}




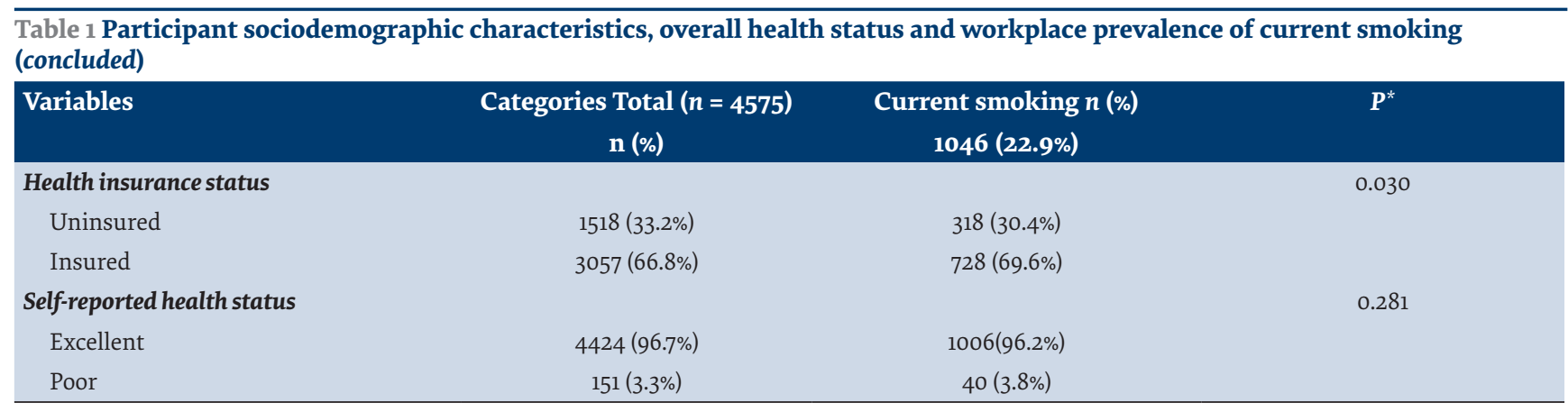

${ }^{*} P$ value derived from $\chi^{2}$ test.

KSA = Kingdom of Saudi Arabia; $S A R=$ Saudi riyal.

for 1-5 years. Expatriate workers that were married and living with their families were less likely to be current smokers. Conversely, being married and residing without their families were significantly associated with current smoking. Unskilled and manual expatriate workers were about 2 times more likely to smoke than professional/ specialist workers. Expatriate workers in all industrial groups had greater odds of smoking, except in the power and utilities sector where there were reduced odds. Relative to expatriate workers who lacked health insurance coverage, insured expatriate workers had 1.3 times greater odds of current smoking.

\section{Discussion}

Smoking is a major public health issue and a global health priority. This is believed to be the first study to investigate the sociodemographics and workplace pattern of smoking among a representative sample of male expatriate workers in Saudi Arabia. The similarities and representativeness of our study sample characteristics to those of the expatriate population have been described elsewhere (12). Our research showed a lower, but comparable prevalence of current smoking (22.9\%) to the WHO estimate (1) of $25.9 \%$ male current smokers in the general population. The highest rate of smoking was in the age group 25-39 years, but in our study it was in the age group 30-49 years. The differences in prevalence and age groups were likely due to differences in the methods of sampling, estimation and age categorization. However, the WHO has estimated $36.1 \%$ male smoking prevalence by 2025 , which is a cause for concern, and has suggested the urgent need for enhanced tobacco control interventions among expatriate workers and the general population to achieve a $30 \%$ relative reduction (15).

Being married and residing with their family were found to be protective against current smoking among expatriate workers. Conversely, being married and not living with the family were significantly associated with current smoking. This may be attributed to the Saudi policy of providing family residence permits to highincome earners, leaving many low-income expatriates to reside without their families (12). In addition, obtaining exit/re-entry visas to visit family members could be difficult as the process depends on the employers. Therefore, a combination of low income and occupational status, residing without their families and difficulties with visiting families could result in stress and loneliness that may increase the urge to smoke to relieve stress and to socialize $(8,16)$. The difference in current smoking between married men residing with and without their families, represents a policy gap that can be addressed by targeting anti-tobacco health initiatives in rental apartments where most married expatriates living without their families reside.

Increased duration of stay was also associated with increased risk of smoking. Expatriate workers resident in Saudi Arabia for $\geq 1$ year had significantly higher odds of current smoking. This finding was consistent with other studies $(17,18)$. One hypothesis is that expatriate workers who stay longer are more likely to adopt the social norms and smoking behaviour of the host country. Therefore, cessation efforts adopting peer education and increased health promotion campaigns using comprehensive and universally accepted anti-tobacco health messages addressing all segments of the population are likely to affect expatriate workers' understanding of tobacco consumption. This is because smoking and acculturation are not only individual but also strong social and group occurrences (19).

Increasing income was a significant risk factor for current smoking among this group. The explanation may be that greater disposable income encourages high earners to take up smoking to symbolize greater social status and acceptance in a social group within which to smoke and socialize (20). However, this was an unanticipated relationship, because research in the general population found an inverse relationship between income and smoking (21). The finding offers important information for targeting smoking. This group could be targeted with peer education and tailored print or web-based cessation materials $(22,23)$.

In addition, having a diploma or university degree was protective against current smoking. These findings are consistent with a growing body of research that suggests socioeconomic characteristics have a strong association with smoking. Differences in smoking prevalence by education level may result from differences in understanding the risk of smoking, increased susceptibility to tobacco marketing, and reflect 


\begin{tabular}{|c|c|c|c|}
\hline \multicolumn{4}{|l|}{ Adjusted OR 95\% CI P } \\
\hline \multicolumn{4}{|l|}{ Maternal language } \\
\hline Arabic & 1.000 & Reference & - \\
\hline Urdu & 0.625 & $0.492-0.793$ & $<0.001$ \\
\hline Hindi & 0.764 & $0.572-1.021$ & 0.069 \\
\hline Malayalam & 1.328 & $0.920-1.919$ & 0.130 \\
\hline Bengali & 0.961 & $0.761-1.213$ & 0.738 \\
\hline Tagalog & 0.885 & $0.601-1.304$ & 0.538 \\
\hline Others & 0.659 & $0.457-0.950$ & 0.026 \\
\hline \multicolumn{4}{|l|}{ Education } \\
\hline Primary school or less & 1.000 & Reference & - \\
\hline Elementary or high school completed & 0.738 & $0.621-0.878$ & 0.001 \\
\hline Diploma or university degree & 0.650 & $0.499-0.847$ & 0.001 \\
\hline \multicolumn{4}{|l|}{ Monthly income (SAR) } \\
\hline$\leq 2000$ & 1.000 & Reference & - \\
\hline $2001-6000$ & 1.309 & $1.045-1.639$ & 0.019 \\
\hline$>6000$ & 3.003 & $1.904-4.734$ & $<0.001$ \\
\hline \multicolumn{4}{|l|}{ Marital status } \\
\hline Single/divorced & 1.000 & Reference & - \\
\hline Married, family in KSA & 0.675 & $0.498-0.916$ & 0.012 \\
\hline Married, family outside KSA & 1.278 & $1.048-1.560$ & 0.016 \\
\hline \multicolumn{4}{|l|}{ Duration of stay in KSA (yr) } \\
\hline$<1$ & 1.000 & - & - \\
\hline $1-5$ & 1.308 & $1.055^{-1.622}$ & 0.015 \\
\hline$>5$ & 1.125 & $0.890-1.422$ & 0.325 \\
\hline \multicolumn{4}{|l|}{ Occupational group } \\
\hline Specialists/professionals & 1.000 & Reference & - \\
\hline Manual workers & 1.600 & $1.234-2.075$ & $<0.001$ \\
\hline Unskilled workers & 1.788 & $1.341-2.383$ & $<0.001$ \\
\hline \multicolumn{4}{|l|}{ Industrial group } \\
\hline Agriculture & 1.000 & Reference & - \\
\hline Mining & 1.730 & $0.864-3.464$ & 0.122 \\
\hline Manufacturing & 1.580 & $0.935-2.670$ & 0.088 \\
\hline Utilities & 0.997 & $0.484-2.053$ & 0.993 \\
\hline Construction & 1.631 & $0.977-2.722$ & 0.061 \\
\hline Trade & 1.316 & $0.789-2.193$ & 0.293 \\
\hline Transportation & 1.639 & $0.927-2.900$ & 0.089 \\
\hline Finance & 1.300 & $0.708-2.390$ & 0.397 \\
\hline Education & 1.144 & $0.674-1.942$ & 0.619 \\
\hline Others & 1.852 & $1.001-3.426$ & 0.050 \\
\hline \multicolumn{4}{|l|}{ Health insurance status } \\
\hline Uninsured & 1.000 & Reference & - \\
\hline Insured & 1.326 & $1.124-1.565$ & 0.001 \\
\hline
\end{tabular}

$C I=$ confidence interval; $O R=$ odds ratio; $S A R=$ Saudi riyal .

knowledge and skills that are important for making health behaviour choices $(24,25)$.

Current smoking probability shows a significant increase for manual and unskilled workers, with the latter having the greater risk. This finding is consistent with other studies in which unskilled workers tended to have higher rates of current smoking than manual workers (26). Factors such as job stress, hazardous working 
conditions, pace of work, socioeconomics and workplace culture of smoking may account for the differences in prevalence among the occupational groups $(26,27)$. Importantly, occupational status strongly correlates with working conditions more than any other socioeconomic characteristics (28). For example, smoking increases the adverse health outcomes of occupational exposure such as increased risk of lung cancer among smokers who are exposed to asbestos. Workplace smoking also exposes colleagues to secondary smoke. Moreover, homes and workplaces are the main sites for exposure to secondary smoke, which also causes lung cancer, heart disease and respiratory illnesses $(11,23,28)$. Effective tobaccocontrol interventions targeting vulnerable sections of expatriates, particularly unskilled workers, are clearly needed.

Although workplace policies and exposure to secondary smoke were not assessed in this study, there is a ban in Saudi Arabia on tobacco smoking in public places, including the workplace but this is not strictly enforced (4). There is an urgent need to integrate comprehensive strategies to reduce the prevalence of tobacco smoking into the Vision 2030 Economic and Development blueprint of Saudi Arabia (29). The rationale is the enormous potential economic and health burdens associated with tobacco smoking. This should include strict monitoring and enforcement of the ban on smoking in public places, including workplaces, advertising, promotion and sponsorship (22,23). Saudi Arabia recently increased taxes on cigarettes. The revenue generated could be used to set up national toll free telephone tobacco cessation lines and training of counsellors to provide cessation advice and therapy (30). Moreover, screening of expatriates for tobacco smoking should be conducted at the medical examination for the issuance of Iqamas (residence permits). Tobacco smokers should be given cessation advice at the medical centres and referred to the cessation lines or free centres offering individual and group smoking cessation counselling and therapy. These interventions could be combined with incentives to reduce tobacco consumption, for example, by offering rewards to expatriate workers who take part in tobacco cessation programmes. Furthermore, our findings support the implementation of the WHO initiative on plain (standardized) packaging of tobacco products to reduce their appeal and increase the effectiveness of health warnings (31).

A notable but unanticipated finding was the increased odds of current smoking among insured expatriate workers. Previous research has suggested that immigrants (20) and individuals in the general population (32) without health insurance are more likely to be current smokers. Additionally, $33 \%$ of our expatriate population lacked health insurance coverage. These findings have implications for healthcare delivery and tobacco cessation interventions. They support the WHO initiatives for universal healthcare coverage in all United Nations member states (33). Crucially, the Ministry of Health and Labour can collaborate with employers to implement policies and programmes to reduce smoking prevalence among expatriate workers. This should include collaborating with insurance companies involved in the compulsory employment-based health insurance to provide comprehensive coverage for effective tobacco cessation counselling and therapy, with no copayments and free access. This would increase access to services, improve the health and well-being of expatriate workers and increase productivity.

Overall, the synergy between increasing income, duration of stay in Saudi Arabia, and insured expatriates, and the interaction between being married and living without family and low occupational status may have contributed to the overall greater odds of smoking. However, the divergence between these groups of factors makes it likely that they contributed individually to the overall effect. This study should help to reach expatriate workers better with tobacco control interventions, as well as to modify existing anti-tobacco health messages better to their needs.

The current study had some limitations. First, the cross-sectional study design limited our ability to make causal inferences. Second, the data in this report represented major occupational groups, which limited identification of specific occupations associated with current smoking. Third, the extent of reporting bias could not be assessed because smoking information was self-reported and not confirmed by blood cotinine tests. However, research that compared serum cotinine levels and self-reported smoking has suggested that selfreported smoking is a valid marker for tobacco exposure (34). Lastly, the findings cannot be generalized to the female expatriate population. A small number of female employees $(98.30 \%$ of all expatriates in the private sector are male) work as housemaids or healthcare workers $(12,35)$. However, the health sector was excluded from the main study that explored expatriates access to healthcare. Moreover, segregation in the workplace would have made it difficult to access and obtain a representative sample of female expatriates. Further research that includes a representative sample of female expatriate workers is required.

\section{Conclusions}

There is an urgent need to integrate into the Vision 2030 Economic and Development blueprint of Saudi Arabia comprehensive strategies to reduce the prevalence of tobacco smoking. This should include the provision of comprehensive insurance coverage for effective tobacco cessation counselling and therapy with free access and no copayments; enforcement of workplace smoking bans; free individual, group and telephone-based cessation counselling; and targeted anti-smoking initiatives at the identified groups integrated with universally accepted anti-tobacco health messages addressing all segments of the population.

Funding: None.

Competing interests: None declared. 


\section{Prévalence et corrélats du tabagisme en milieu de travail chez les travailleurs expatriés de sexe masculin en Arabie saoudite}

\section{Résumé}

Contexte : Les populations immigrées en Arabie saoudite sont confrontées à des inégalités importantes en matière de santé, y compris une plus forte prévalence du tabagisme et un taux de sevrage plus faible. Le tabagisme chez les travailleurs expatriés reste cependant un sujet méconnu.

Objectifs : Déterminer la prévalence et les corrélats du tabagisme en milieu de travail au moment de l'étude afin de mettre en œuvre des interventions antitabac ciblées.

Méthodes : Une étude transversale a été réalisée auprès de 4575 travailleurs expatriés de sexe masculin afin d'étudier les liens entre le tabagisme auto-déclaré, les caractéristiques sociodémographiques, le secteur et la profession, le régime d'assurance maladie et l'état de santé global en recourant aux analyses de régression logistique.

Résultats: La prévalence du tabagisme au moment de l'étude était de $22,9 \%$ chez les travailleurs expatriés de sexe masculin, soit plus faible que la prévalence estimée dans la population générale (25,9\%). Les facteurs étroitement associés au tabagisme incluaient le fait d'être marié sans vivre avec la famille (odds ratio ajusté [ORa] = 1,278; intervalle de confiance [IC] à $95 \%$ : 1,048-1,560), la couverture d'assurance-maladie (ORa= 1,326; IC à 95\%:1,124-1,565), le travail manuel $(\mathrm{ORa}=1,600$; IC à 95\%:1,234-2,075) et le fait d'être non qualifié (ORa = 1,788; IC à 95\%:1,341-2,383), un revenu mensuel supérieur à 2000 rials saoudiens et une durée de séjour supérieure ou égale à un an.

Conclusions : Des efforts concertés doivent être mis en œuvre par le gouvernement national (politiques de santé) et par les employeurs pour réduire la prévalence du tabagisme chez les travailleurs expatriés de sexe masculin, notamment par la fourniture d'une assurance maladie complète couvrant les thérapies de sevrage tabagique, l'application de l'interdiction de fumer sur les lieux de travail ainsi que la mise en place de programmes de prévention du tabagisme et de services de conseil en matière de sevrage tabagique (en ligne ou par téléphone).

$$
\begin{aligned}
& \text { معدلات انتشار تدخين التبغ بين العاملين المغتربين الذكور وارتباطها بمكان العمل في المملكة العربية السعودية } \\
& \text { هايسن اوكوهور، الخميس عبد الوهاب الخميس } \\
& \text { الخلاصة }
\end{aligned}
$$

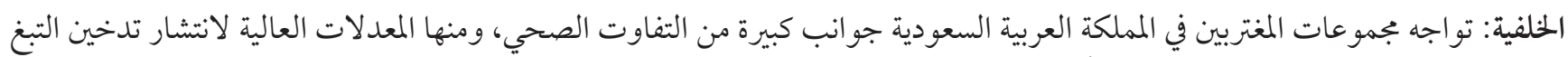

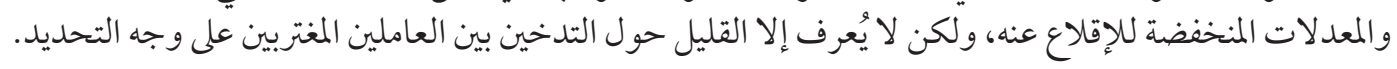

$$
\begin{aligned}
& \text { الأهداف: هدفت هذه الدراسة إلى التعرف على الارتباطات بين معدل الانتشار الحالي للتدخين ومكان العمل، تمهيدًا لتدخلات تستهدف الإقلاع } \\
& \text { عنه. }
\end{aligned}
$$

\section{References}

1. WHO global report on trends in prevalence of tobacco smoking 2015.Geneva: World Health Organization; 2015 (http://apps.who. int/iris/bitstream/handle/10665/156262/9789241564922_eng.pdf;jsessionid=16191B5C82926851B05E83339C8CBoC1?sequence=1, accessed 19 July 2018).

2. Thun M, Peto R, Boreham J, Lopez AD. Stages of the cigarette epidemic on entering its second century. Tob Control. 2012 Mar;21(2):96-101. https://doi.org/10.1136/tobaccocontrol-2011-050294 PMID:22345230 
3. Al Moamary MS. Tobacco consummation: Is it still a dilemma? Ann Thorac Med. 2010 Oct;5(4):193-4. https://doi.org/10.4103/18171737.69103 PMID:20981178

4. The tobacco atlas. Saudi Arabia [website] (http://www.tobaccoatlas.org/country-data/saudi-arabia/, accessed 19 July 2018).

5. Moradi-Lakeh M, El Bcheraoui C, Tuffaha M, Daoud F, Al Saeedi M, Basulaiman M, et al. Tobacco consumption in the Kingdom of Saudi Arabia, 2013: findings from a national survey. BMC Public Health. 2015 Jul 5;15(1):611. https://doi.org/10.1186/s12889-0151902-3 PMID:26141062

6. Draft comprehensive global monitoring framework and targets for the prevention and control of noncommunicable diseases. Formal meeting of the Member States to conclude the work on the comprehensive global monitoring framework, including indicators, and a set of voluntary global targets for the prevention and control of noncommunicable diseases. Report by the Director-General. Geneva: World Health Organization; 2013(http://www.who.int/iris/handle/10665/105633, accessed 19 July 2018).

7. Kontis V, Mathers CD, Bonita R, Stevens GA, Rehm J, Shield KD, et al. Regional contributions of six preventable risk factors to achieving the $25 \times 25$ non-communicable disease mortality reduction target: a modelling study. Lancet Glob Health. 2015 Dec; 3(12):e746-57. https://doi.org/10.1016/S2214-109X(15)00179-5 PMID:26497599

8. Ahmad MS. Prevalence and attitude of cigarette smoking among Indian expatriates living in Jeddah, Kingdom of Saudi Arabia. J Int Oral Health. 2015 Jun;7(6):9-12. PMID:26124592

9. Centers for Disease Control and Prevention (CDC). Racial/ethnic disparities and geographic differences in lung cancer incidence - 38 States and the District of Columbia, 1998-2006.MMWR Morb Mortal Wkly Rep. 2010 Nov 12;59(44):1434-8. PMID:21063273

10. Giuliani KK, Mire O, Leinberger-Jabari A, Ehrlich LC, Stigler MH, Pryce DJ, et al. Cigarettes and the Somali diaspora: tobacco use among Somali adults in Minnesota. Am J Prev Med. 2012 Nov; 43(5) Suppl 3:S205-13. https://doi.org/10.1016/j.amepre.2012.08.002 PMID:23079218

11. Centers for Disease Control and Prevention (CDC). Current cigarette smoking prevalence among working adults-United States, 2004-2010.MMWR Morb Mortal Wkly Rep. 2011 Sep 30;60(38):1305-9. PMID:21956406

12. Alkhamis A, Cosgrove P, Mohamed G, Hassan A. The personal and workplace characteristics of uninsured expatriate males in Saudi Arabia. BMC Health Serv Res. 2017 Jan 19;17(1):56. https://doi.org/10.1186/s12913-017-1985-x PMID:28103858

13. Global Adult Tobacco Survey Collaborative Group. Tobacco questions for surveys: a subset of key questions from the Global Adult Tobacco Survey (GATS), 2nd edition. Atlanta: Centers for Disease Control and Prevention; 2011 (http://www.who.int/tobacco/surveillance/en_tfi_tqs.pdf, accessed 19 July 2018).

14. Agency for Healthcare Research and Quality. Medical Expenditure Panel Survey, household (HC) questionnaire sections [website]; 2009 (http://www.meps.ahrq.gov/mepsweb/survey_comp/survey.jsp, accessed 19 July 2018).

15. Bilano V, Gilmour S, Moffiet T, d'Espaignet ET, Stevens GA, Commar A, et al. Global trends and projections for tobacco use, 1990-2025: an analysis of smoking indicators from the WHO Comprehensive Information Systems for Tobacco Control. Lancet. 2015 Mar 14; 385(9972):966-76.https://doi.org/10.1016/S0140-6736(15)60264-1 PMID:25784347

16. Scollo M, Winstanley M. Tobacco in Australia: facts and issues. Melbourne: Cancer Council Victoria; 2018 [website] (http://www. tobaccoinaustralia.org.au/, accessed 19 July 2018).

17. An N, Cochran SD, Mays VM, McCarthy WJ. Influence of American acculturation on cigarette smoking behaviors among Asian American subpopulations in California. Nicotine Tob Res. 2008 Apr; 10(4):579-87. https://doi.org/10.1080/14622200801979126 PMID:18418780

18. Reiss K, Sauzet O, Breckenkamp J, Spallek J, Razum O. How immigrants adapt their smoking behaviour: comparative analysis among Turkish immigrants in Germany and the Netherlands. BMC Public Health. 2014 Aug 14;14(1):844. https://doi. org/10.1186/1471-2458-14-844 PMID:25124365

19. Reiss K, Schunck R, Razum O. Effect of length of stay on smoking among Turkish and Eastern European immigrants in Germany - interpretation in the light of the smoking epidemic model and the acculturation theory.Int J Environ Res Public Health. 2015 Dec 15;12(12):15925-36. https://doi.org/10.3390/ijerph121215030 PMID:26694430

20. Mou J, Fellmeth G, Griffiths S, Dawes M, Cheng J. Tobacco smoking among migrant factory workers in Shenzhen, China. Nicotine Tob Res. 2013 Jan;15(1):69-76. https://doi.org/10.1093/ntr/nts085 PMID:22492086

21. Systematic review of the link between tobacco and poverty. Geneva: World Health Organization; 2011 (http://apps.who.int/iris/ bitstream/handle/10665/44453/9789241500548_eng.pdf?sequence=1, accessed 19 July 2018).

22. 22. Cahill K, Lancaster T. Workplace interventions for smoking cessation. Cochrane Database Syst Rev. 2014 Feb 26;(2):CDoo3440. PMID:24570145

23. 23. The health consequences of involuntary exposure to tobacco smoke: a report of the Surgeon General. Atlanta: U.S. Department of Health and Human Services, Centers for Disease Control and Prevention, Coordinating Center for Health Promotion, National Center for Chronic Disease Prevention and Health Promotion, Office on Smoking and Health; 2006 (https://www. surgeongeneral.gov/library/reports/secondhandsmoke/fullreport.pdf, accessed 19 July 2018).

24. Laaksonen M, Rahkonen O, Karvonen S, Lahelma E. Socioeconomic status and smoking. Analysing inequalities with multiple indicators. Eur J Public Health.2005 Jun;15(3):262-9.https://doi.org/10.1093/eurpub/cki115 PMID:15755781

25. Backlund E, Sorlie PD, Johnson NJ. A comparison of the relationships of education and income with mortality: the National Longitudinal Mortality Study. Soc Sci Med. 1999 Nov;49(10):1373-84. https://doi.org/10.1016/So277-9536(99)00209-9 PMID:10509827 
26. Ham DC, Przybeck T, Strickland JR, Luke DA, Bierut LJ, Evanoff BA. Occupation and workplace policies predict smoking behaviors: analysis of national data from the current population survey. J Occup Environ Med. 2011 Nov;53(11):1337-45. https://doi. org/10.1097/JOM.obo13e3182337778 PMID:21988795

27. Sorensen G, Barbeau E, Hunt MK, Emmons K. Reducing social disparities in tobacco use: a social-contextual model for reducing tobacco use among blue-collar workers. Am J Public Health. 2004 Feb;94(2):230-9. https://doi.org/10.2105/AJPH.94.2.230 PMID:14759932

28. Centers for Disease Control and Prevention (CDC). Smoking-attributable mortality, years of potential life lost, and productivity losses - United States, 2000-2004.MMWR Morb Mortal Wkly Rep. 2008 Nov 14;57(45):1226-8. PMID:19008791

29. Council of Economic and Development Affairs Vision 2030. Saudi Arabia; 2016 (http://vision2030.gov.sa/en, accessed 19 July 2018).

30. Training for tobacco quit line counsellors: telephone counselling. Geneva: World Health Organization; 2014 (http://apps.who.int/ iris/bitstream/handle/10665/113145/9789241507264_eng.pdf?sequence=1, accessed 19 July 2018).

31. Get ready for plain packaging. Geneva: World Health Organization; 2016 (http://www.who.int/campaigns/no-tobacco-day/2016/ brochure/en/, accessed 19 July 2018).

32. Wilper AP, Woolhandler S, Lasser KE, McCormick D, Bor DH, Himmelstein DU. Health insurance and mortality in US adults. Am J Public Health. 2009 Dec;99(12):2289-95. https://doi.org/10.2105/AJPH.2008.157685 PMID:19762659

33. Together on the road to universal health coverage. A call to action. Geneva: World Health Organization; 2017 (http://www.who. int/universal_health_coverage/road-to-uhc/en/, accessed 10 August 2018).

34. Tennekoon V, Rosenman R. The pot calling the kettle black? A comparison of measures of current tobacco use. Appl Econ. 2015 Jan;47(5):431-48. https://doi.org/10.1080/00036846.2014.972546 PMID:25587199

35. Alswaidi F, Memish Z, Al Hakeem R, Atlam S. Saudi Arabian expatriate worker fitness-screening programme: a review of 14 years of data. East Mediterr Health J. 2013 Jul;19(7):664-70.PMID:24975313 